\title{
Extraction of Oleoresin from Pungent Red Paprika Under Different Conditions
}

\author{
Vesna Rafajlovska ${ }^{1}$, Renata Slaveska-Raicki², \\ Jana Klopcevska ${ }^{1}$ and Marija Srbinoska ${ }^{3}$ \\ ${ }^{1}$ Ss. Cyril and Methodius University in Skopje, \\ Faculty of Technology and Metallurgy, Skopje \\ ${ }^{2}$ Ss. Cyril and Methodius University in Skopje, Faculty of Pharmacy, Skopje \\ ${ }^{3}$ University St. Kliment Ohridski-Bitola, Scientific Tobacco Institute, Prilep, \\ Republic of Macedonia
}

\section{Introduction}

The significance of and interest in pungent paprika have been growing over the years due to its high potential to provide a broad spectrum of products with important medicinal and commercial value (Govindarajan \& Sathyanarayana, 1991; Guzman et al., 2011; Pruthi, 2003). As a rich source of characteristic phytocompounds, pungent paprika has a notable place in modern food and in pharmaceutical industries (De Marino et al., 2008).

As acknowledged, the principal pungent constituent of pungent paprika is capsaicin, an alkaloid or predominant capsaicinoid, followed by dihydrocapsaicin, nordihydrocapsaicin, homodihydrocapsaicin and homocapsaicin (Davis et al., 2007; Hoffman et al., 1983). Although there are two geometric isomers of capsaicin, only trans-capsaicin occurs naturally, and thus the term 'capsaicin' is generically used to refer to the trans-geometric isomer. The capsaicin content of pungent paprika ranges from 0.1 to $1 \% \mathrm{w} / \mathrm{w}$ (Barbero et al., 2006; Govindarajan \& Sathyanarayana, 1991).

Over the years, capsaicin, a promising molecule with many possible clinical applications, has been comprehensively studied (experimentally, clinically and epidemiologically) owing to its prominent antioxidant, antimicrobial and anti-inflammatory properties (Dorantes et al., 2000; Materska \& Peruska, 2005; Reyes-Escogido et al., 2011; Singh \& Chittenden, 2008; Xing et al., 2006; Xiu-Ju et al., 2011). Many studies give evidence that capsaicin has been widely used as the potent active ingredient incorporated into a wide range of topical analgesic formulations (Weisshaar et al., 2003, Ying-Yue et al. 2001). Moreover, considerable interest has developed in expanding the usage of capsaicinoids in other forms such as natural product-based food additive, dietary supplements and as constituent in self-defense products (Dorantes et al., 2000; Materska \& Perucka, 2005; Nowaczyk et al., 2008; Spicer \& Almirall, 2005; Xing et al., 2006). In addition, the recent results showing their possible therapeutic effects in obesity treatment have further increased the importance of capsaicinoids (Ji-Hye et al., 2010).

One of the most common pungent paprika products is pungent capsicum oleoresin (PCO), an organic oily resin derived from the dried ripe fruits of pungent varieties of Capsicum annuи L., by means of solid-liquid extraction and subsequent solvent removal (Cvetkov \& 
Rafajlovska, 1992; Kense, 1970; Rajaraman et al., 1981). Basically, PCO contains pigments carotenoids predominantly capsanthin (Giovannucci, 2002, Hornero-Méndez et al., 2000; Matsufuji et al., 1998) and not less than eight percent of total capsacinoids. Furthermore, beside the pigments, chemical entities such as flavors, taste agents, vitamins and fatty oil are also present in the PCO components profile (Howard et al., 1994; Vinaz et al., 1992). However, a survey of literature reveals that, generally, the most commonly employed and a preferred method for extraction of compounds present in plant matrices is the conventional solid-liquid extraction using organic solvents. In later studies, these conventional methods were improved, modified or rationalized by varying different operating parameters (Boonkird et al., 2008; Toma et al., 2001; Vinatoru, 2001; Wang \& Weller, 2006).

The paprika oleoresins are produced by solvent extraction of dried, ground red pepper fruits, using a solvent-system compatible with the lipophilic/hydrophilic characteristics of the extract sought and subsequent solvent-system removal. The solvents most commonly used for paprika oleoresin extraction are trichloroethylene, ethylacetate, acetone, propan-2ol, methanol, ethanol and n-hexane (Cvetkov \& Rafajlovska, 1992; Hornero-Méndez et al., 2000; Kense, 1970).

Although many studies have been published on the development and implementation of the different operating conditions for PCO recovery, little attention seems to have been given to the optimization of the various extraction variables (e.g. the appropriate solvent, temperature, dynamic extraction time, quantity of sample, etc.) nor has a systematic study for the optimization of the method been carried out. Therefore, in a situation, where multiple variables may influence the extraction yield, application of a response surface methodology (RSM) to optimize the extraction condition offers an effective technique for studying and optimizing the process and operating parameters (Acero-Ortega et al., 2005; Giovanni, 1983; Li \& Fu, 2005; Montgomery, 2001).

As part of our contribution to the studies on extraction methods for pungent red paprika we have carried out organic solvent extraction procedure under different conditions, resulting in optimized conditions for the matrix compounds from Capsicum annuum L. Hence, the principal goals were to study the influence of the solvent type, extraction temperature and dynamic time on pungent red paprika extraction efficiency expressed by PCO yield and capsaicin and capsanthin content in it and to establish mathematical models to predict system responses.

\section{Materials and methods}

\subsection{Plant material}

Red pungent dried paprika fruits or, more precisely, pericarp (Capsicum annuum L., ssp. microcarpum longum conoides, convar. Horgos) used in this study were obtained from the Markova Ceshma region, Prilep, Republic of Macedonia. The pepper species was authenticated by Prof. Danail Jankulovski, Faculty of Agricultural Sciences and Food, Skopje, Republic of Macedonia. A voucher specimen (\#1035) is deposited there. The dried pericarp was ground using Retsch ZM1 mill (Germany) and sieved ( $0.250 \mathrm{~mm}$ particle size). The paprika samples placed in dark glass bottles were stored at $4^{\circ} \mathrm{C}$ in refrigerator.

\subsection{Extraction procedure}

The impact of three different solvents (ethanol, methanol and $n$-hexane) on the PCO yield, capsaicin and capsanthin content in it were explored using maceration by solid:liquid ratio 1:20 w/v. A $1 \mathrm{~g}$ paprika sample (0.0001 g accurately weighed) was used in preparation of 
single extract. Furthermore, for extraction parameter study at different temperature and time, the extraction was carried out in thermostatic water bath at a temperature of $30,40,50$, 60 and $70^{\circ} \mathrm{C}$, respectively with the exception of $70^{\circ} \mathrm{C}$ when ethanol was utilized. The effect of dynamic extraction time on the analyte of interest was followed during 60, 120, 180 and 300 min, respectively. After extraction for selected time and at maintained temperature, the solvent was removed under vacuum (rotary vacuum evaporator, type Devarot, Slovenia, $35^{\circ} \mathrm{C}$, atm. pressure). Solvent traces were discharged by drying the sample at $40^{\circ} \mathrm{C}, 105 \mathrm{mPa}$ (vacuum drier, Heraeus Vacutherm VT 6025, Langenselbold, Germany). Each extraction procedure was performed in duplicate under the same operating conditions.

\subsection{Determination of pungent capsicum oleoresin yield}

Obtained PCOs were cooled in a desiccator and weighed. The steps of drying, cooling and weighing were repeated until the difference between two consecutive weights was smaller than $2 \mathrm{mg}$. The PCO yield was estimated according to dry matter weight in extracted quantity of red pungent paprika. The extract was transferred into a $100 \mathrm{~mL}$ volumetric flask and filled to $100 \mathrm{~mL}$ with ethanol (1st dissolution).

\subsection{Determination of capsaicin content in pungent capsicum oleoresin}

The capsaicin content in the extracts was determined by reading of the absorbance at 282 $\mathrm{nm}$. Actually, $0.5 \mathrm{~mL}$ of $1^{\text {st }}$ dissolution was dissolved and filled up to $10 \mathrm{~mL}$ with ethanol and the absorbance was measured. The concentration of capsaicin was estimated from the standard curve for capsaicin given by the Eq. (1).

$$
y=9.64 x+0.005 \quad R^{2}=0.9909
$$

where $\mathrm{x}=\mu \mathrm{g}$ capsaicin $/ \mathrm{mL}$ extract and $\mathrm{y}=$ absorbance.

\subsection{Determination of capsanthin content in pungent capsicum oleoresin}

Pigments concentration in red pungent paprika extract was calculated using the extinction coefficient of the major pigment capsanthin $\left(1 \% \mathrm{E}_{460 \mathrm{~nm}}=2300\right)$ in acetone (Hornero-Méndez et al., 2000).

\subsection{Apparatus}

The spectrophotometric measurements were carried out on a Varian Cary Scan 50 spectrophotometer (Switzerland) in $1 \mathrm{~cm}$ quartz cells, at $25^{\circ} \mathrm{C}$.

\subsection{Statistical analysis}

The statistical analysis and evaluation of the data were performed using STATISTICA 8 (StaSoft, Inc., Tulsa, USA) software. A two-predictors non linear regression model was used to evaluate the individual and interactive effects of two-independent variables, extraction temperature $\left(\mathrm{x}_{1}\right)$ and dynamic time $\left(\mathrm{x}_{2}\right)$. The responses measured were PCO yield, capsaicin and major pigment capsanthin present in the PCO.

The second order model includes linear, quadratic and interactive terms thus, in the responses function $(\mathrm{Y})$-Eq. $2, \mathrm{x}_{\mathrm{i}}$ and $\mathrm{x}_{\mathrm{j}}$ are predictors; $\beta_{0}$ is the intercept; $\beta_{\mathrm{i}}$ are linear coefficients; $\beta_{\mathrm{ii}}$ are squared coefficients; $\beta_{\mathrm{ij}}$ are interaction coefficients and $\varepsilon$ is an error term. 


$$
\mathrm{Y}=\beta_{\mathrm{o}}+\sum_{\mathrm{i}=1}^{\mathrm{k}} \beta_{\mathrm{i}} X_{1}+\sum_{\mathrm{i}=1}^{\mathrm{k}} \beta_{\mathrm{ii}} X_{2}+\sum_{\mathrm{i} \succ 1}^{\mathrm{k}} \beta_{\mathrm{ij}} X_{i} X_{j}+\varepsilon
$$

ANOVA was used to evaluate the significances of the coefficients of the models judged by computing the $F$-value at a probability $(p)$ of $0.001,0.01$ and 0.05 .

The influence of the predictors on the responses was also presented using 3-D mesh plots and contour maps.

\section{Results and discussion}

As acknowledged, the selection of the most appropriate solvent for extracting the analytes of interest from the plant matrix is a basic step in the development of any method of solvent extraction. Theoretically, solvent would provide not only a background for the extraction process but it would also stabilize the analytes and the transition state species by solvating process. This solvation is due to solvent-analyte interactions during which a solvent acts either as a nucleophile or as an electrophile by donating or accepting electron pairs from the analyte. The research data evidence for hot pepper cultivars indicate that methanol and ethanol are solvents usually used in the extraction of capsaicinoids in various extraction techniques (Barbero et al., 2006; Kirschbamm-Titze et al., 2002; Williams et al. 2007). Studies on the solvent influence on pigments extraction from Capsicum fruits ascertained $n$-hexane and acetone as suitable solvent medium for pigments (Boyadzhiev et al., 1999; Feltl et al., 2005; Tepić et al., 2009).

Evidence provided by relevant literature positively confirm recent growing interest in the development of mathematical models that describe the extraction process as a function of various operational variables and, particularly, those that describe their combined effect (Acero-Ortega et al., 2005; Bo et al., 2008; Hismath et al., 2011; Liu et al., 2010).

In order to select the extraction solvent for pungent paprika matrix, experiments were performed with three solvents: ethanol, methanol and $n$-hexane. According to our previous experiences (Rafajlovska et al., 2007), the two variables that could potentially affect the extraction efficiency of the analytes of interest in chosen solvents are extraction temperature and dynamic time. Owing to the significance of interaction between time and temperature, their interactive influence on the extraction efficiency was also considered. Other parameters implicated in the extraction were kept constant, namely the solid:phase ratio and particles size.

\subsection{Extraction of pungent capsicum oleoresin, capsaicin and capsanthin with ethanol 3.1.1 Model fitting}

Table 1 shows the liner, quadratic and interactive coefficients of the independent variables in the models and their corresponding $\mathrm{R}^{2}$ when ethanol was used as extraction solvent. It can be seen that the $\mathrm{R}^{2}$ values for these response variables are higher than 0.97 where PCO and capsaicin are concerned, indicating that the regression models adequately explained the process. Therefore, the $\mathrm{R}^{2}$ values are 0.9795 and 0.9810 , respectively, for PCO yield and capsanthin. The probability $(p)$ values of regression models for PCO and capsaicin show no lack-of-fit ( $\mathrm{p}<0.001)$. However, since the $\mathrm{R}^{2}$ value of capsanthin is not acceptable $\left(\mathrm{R}^{2}=0.7890\right)$ this regression model is not suitable to explicate the extraction process for capsanthin, probably owing to the solvent characteristics. 


\begin{tabular}{lccc}
\hline & Yield $(\%)$ & Capsaicin $(\mathrm{mg} / 100 \mathrm{~g})$ & Capsanthin $(\mathrm{mg} / 100 \mathrm{~g})$ \\
\hline $\mathrm{b}_{\mathrm{o}}$ (intercept) & 3.153322 & 186.625700 & 117.141400 \\
$\mathrm{~b}_{1}$ & $0.260120^{* * *}$ & -0.262400 & 3.238900 \\
$\mathrm{~b}_{2}$ & $0.025702^{* *}$ & 0.063600 & $0.987800^{* * *}$ \\
$\mathrm{~b}_{1}{ }^{2}$ & -0.000452 & 0.010700 & -0.023000 \\
$\mathrm{~b}_{2}{ }^{2}$ & -0.000010 & $-0.000500^{* *}$ & -0.000800 \\
$\mathrm{~b}_{12}$ & $-0.000286^{* *}$ & $0.004800^{* * *}$ & $-0.012200^{* * *}$ \\
$R^{2}$ & 0.9795 & 0.9810 & 0.7890 \\
adjusted R 2 & 0.9722 & 0.9742 & 0.7138 \\
$p$ or probability & 0.0000 & 0.0000 & 0.0002 \\
\hline
\end{tabular}

Subscripts: $1=$ temperature $\left({ }^{\circ} \mathrm{C}\right) ; 2$ = time $(\mathrm{min})$;

*Significant at 0.05 level; **Significant at 0.01 level; ***Significant at 0.001 level.

Table 1. Regression coefficients, $R^{2}$, adjusted $\mathrm{R}^{2}$ and $p$ for three dependent variables for pungent capsicum oleoresin obtained by ethanol.

\subsubsection{Influence of extraction temperature and time}

The influence of extraction conditions on the PCO yield and capsaicin were presented by the coefficients of the second-order polynomials. As shown in Table 2, PCO yield was significantly affected by the positive linear effect $(p<0.001)$ of the temperature and the positive linear effect $(p<0.01)$ of the time. In this case, the temperature and time were relevant variables for the model. However, significant linear interaction between the temperature and time $(p<0.01)$ had a negative sign. Moreover, it was found that the influence in the second-order term for the both variables showed no significant effect $(p>$ 0.05). These results suggest that the linear effect of the extraction temperature was the primary determining factor for PCO yield but there is no need for prolonged solid/liquid phase contact. The response surface and contour map were also developed to facilitate the visualization and latter, for predicting the optimum condition for PCO yield and capsaicin in ethanol (Fig. 1).

Fig. $1 \mathrm{~b}$ shows that the PCO yield increased as the temperature increased. As for the capsaicin content in $\mathrm{PCO}$, the positive interaction among the independent variables $(\mathrm{p}<$ 0.001 ) significantly influenced the capsaicin content. It was also found that quadratic effect of extraction time is negative at $\mathrm{p}<0.01$. However, the linear term of temperature and time showed no significant effect on capsaicin content in ethanolic PCO. Hence, when analyzing the interactive effect of temperature and time on the extraction efficiency of capsaicin (Fig. 2) in the model developed for ethanol as extraction solvent, it was observed that extended time of extraction is not appropriate under increased temperature condition.

Fig. 3 shows that owing to the capsanthin temperature liability (Ahmeda et al., 2002; PérezGálvez et al., 2005; Schweiggert et al., 2007), capsanthin extraction in ethanolic medium should be performed at decreased temperature of about $40^{\circ} \mathrm{C}$ at most during extended time. 


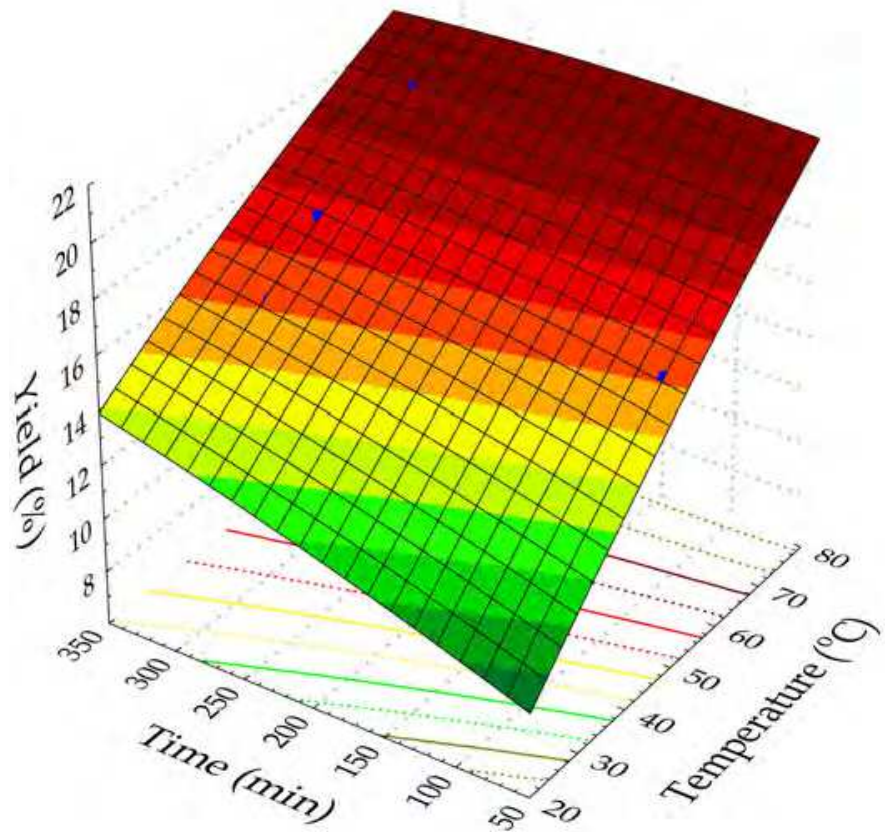

(a)

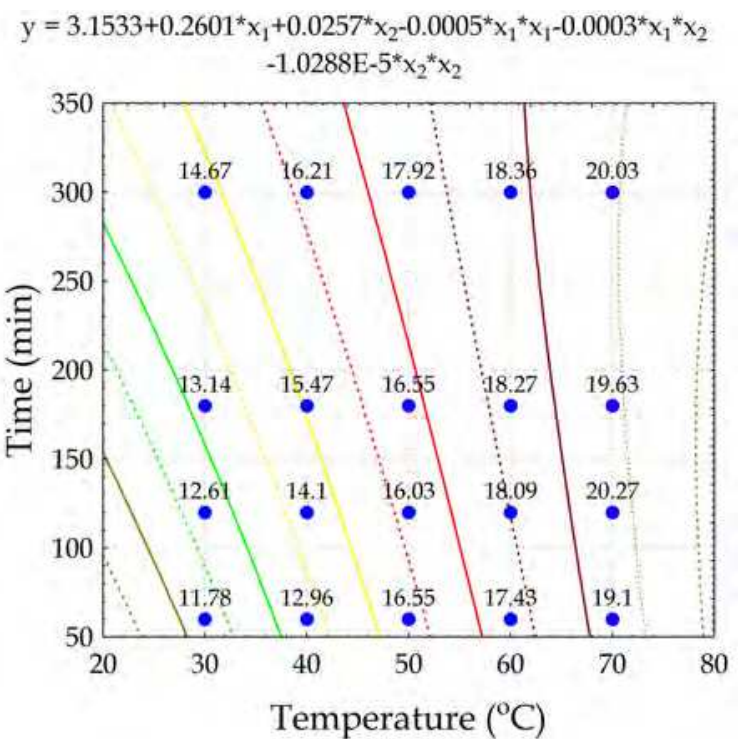

(b)

Fig. 1. 3-D mesh plot (a) and contour plot (b) of the effects of extraction temperature and time on PCO yield (\%) in ethanol. 


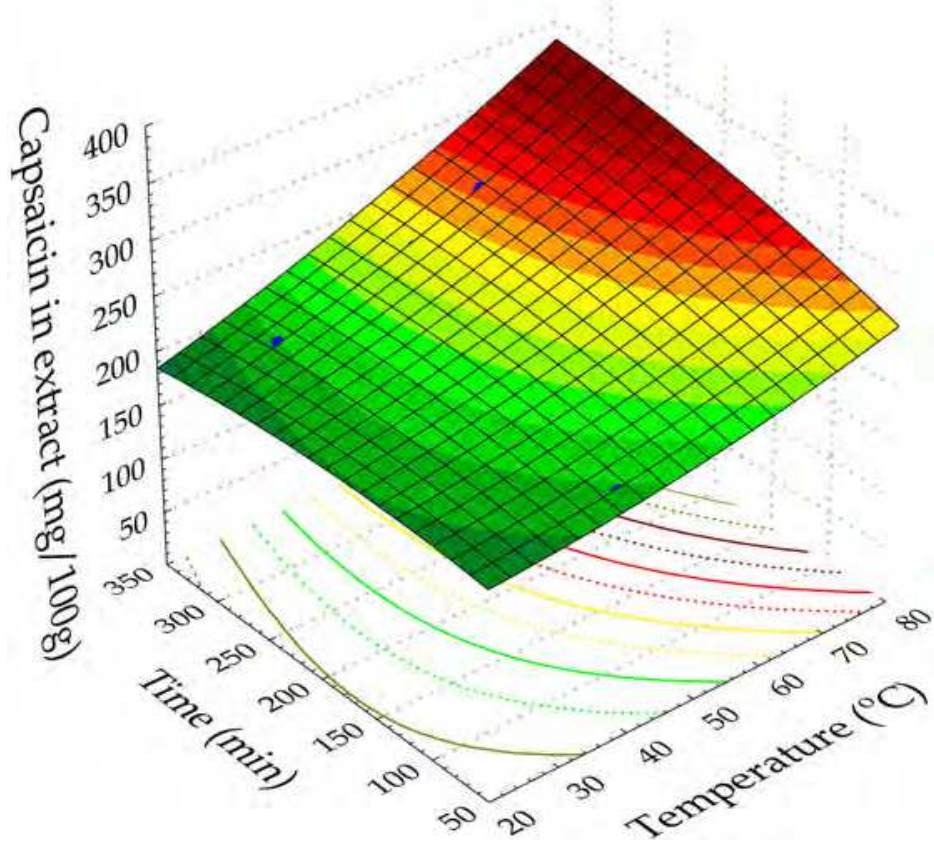

(a)

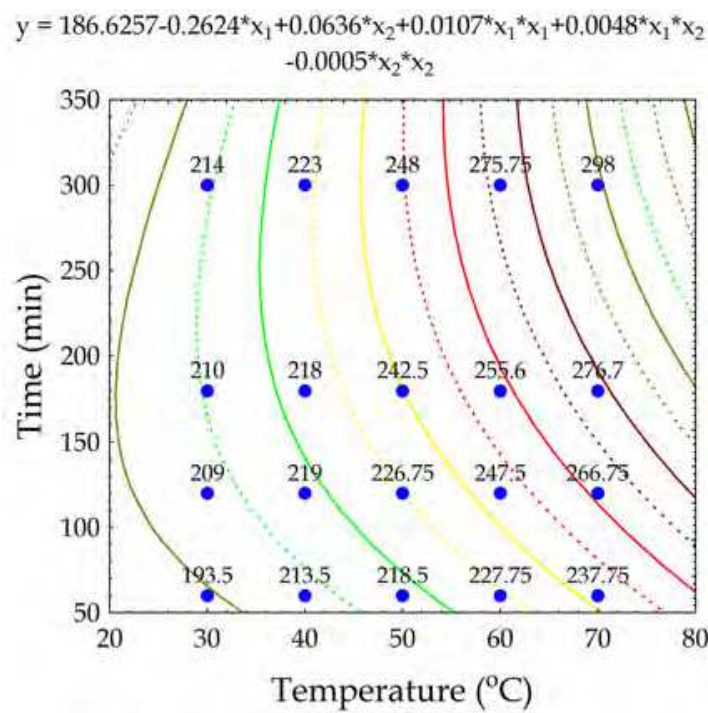

(b)

Fig. 2. 3-D mesh plot (a) and contour plot (b) of the effects of extraction temperature and time on capsaicin in ethanolic PCO. 


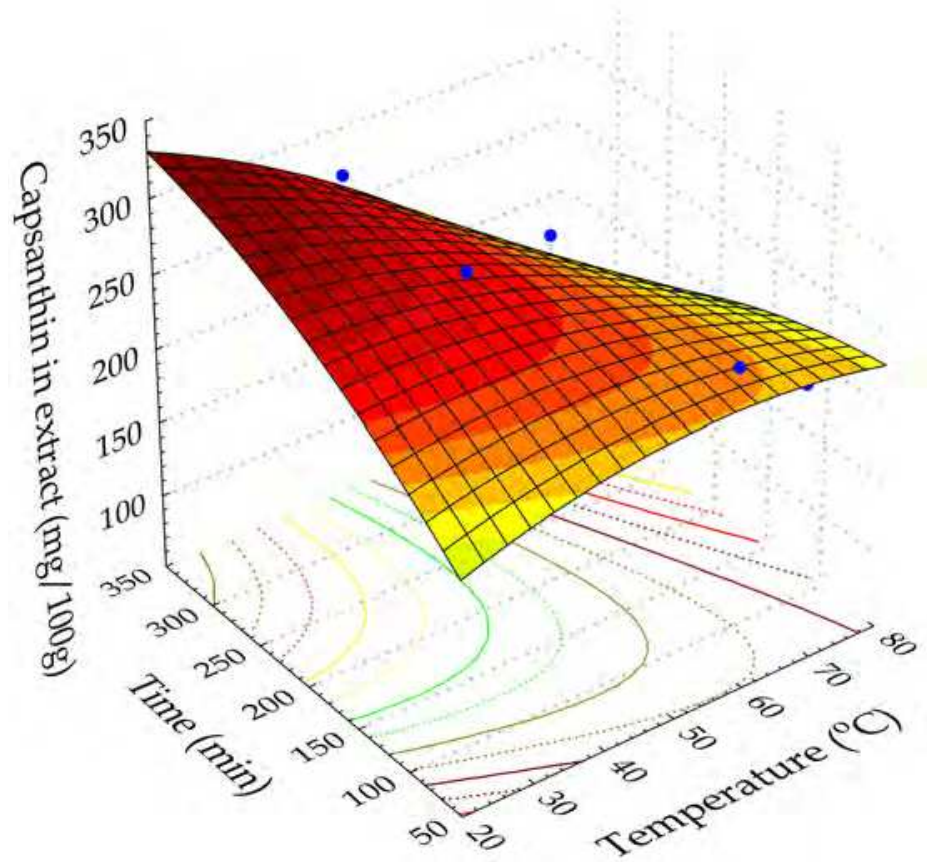

(a)

$$
\begin{gathered}
y=117.1414+3.2389^{*} x_{1}+0.9878^{*} x_{2}-0.023^{*} x_{1}{ }^{*} x_{1}-0.0122^{*} x_{1}{ }^{*} x_{2} \\
-0.0008^{*} x_{2}{ }^{*} x_{2}
\end{gathered}
$$

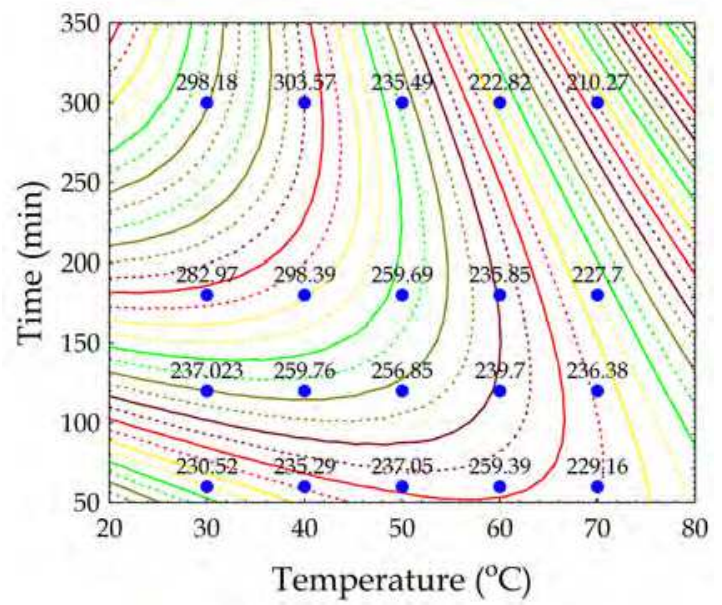

(b)

Fig. 3. 3-D mesh plot (a) and contour plot (b) of the effects of extraction temperature and time on capsanthin in ethanolic PCO. 


\subsection{Extraction of pungent capsicum oleoresin, capsaicin and capsanthin with methanol \\ 3.2.1 Model fitting}

The liner, quadratic and interactive coefficients of the independent variables in the models and their corresponding $\mathrm{R}^{2}$ when methanol was used as extraction solvent are presented in Table 2.

\begin{tabular}{lccc}
\hline & Yield $(\%)$ & Capsaicin $(\mathrm{mg} / 100 \mathrm{~g})$ & Capsanthin $(\mathrm{mg} / 100 \mathrm{~g})$ \\
\hline $\mathrm{b}_{\mathrm{o}}$ (intercept) & 4.938929 & 16.501750 & -56.065700 \\
$\mathrm{~b}_{1}$ & 0.282113 & $6.922010^{*}$ & $9.785980^{* *}$ \\
$\mathrm{~b}_{2}$ & $0.036924^{*}$ & 0.324730 & $0.808700^{* *}$ \\
$\mathrm{~b}_{1}{ }^{2}$ & -0.002389 & $-0.087330^{* *}$ & $-0.097400^{*}$ \\
$\mathrm{~b}_{2}{ }^{2}$ & -0.000051 & $-0.001700^{* *}$ & $-0.001300^{*}$ \\
$\mathrm{~b}_{12}$ & 0.000337 & $0.012620^{* * *}$ & $-0.006600^{* *}$ \\
$R^{2}$ & 0.9702 & 0.9391 & 0.7228 \\
adjusted R & 0.9553 & 0.9087 & 0.5843 \\
$p$ or probability & 0.0000 & 0.0000 & 0.0130 \\
\hline
\end{tabular}

Subscripts: 1 = temperature $\left({ }^{\circ} \mathrm{C}\right) ; 2$ = time $(\mathrm{min})$;

*Significant at 0.05 level; **Significant at 0.01 level; ***Significant at 0.001 level.

Table 2. Regression coefficients, $R^{2}$, adjusted $R^{2}$ and $p$ for three dependent variables for pungent capsicum oleoresin obtained by methanol.

Table 2 clearly shows that the $\mathrm{R}^{2}$ values for these response variables are higher than 0.93 for both PCO and capsaicin, indicating that the regression models adequately explain the process. Hence, the $\mathrm{R}^{2}$ values are 0.9702 and 0.9391 , respectively, for methanolic PCO yield and capsaicin. The $p$ values of regression models for PCO yield and capsanthin show no lack-of-fit. However, as expected, the $\mathrm{R}^{2}$ value of capsanthin is low, $\left(\mathrm{R}^{2}=0.7228\right)$ confirming that a high proportion of variability is not explained by the model. We therefore conclude that this regression model cannot offer a satisfactory explanation of the extraction process for capsanthin.

\subsubsection{Influence of extraction temperature and time}

The influence of extraction conditions on the PCO, capsaicin and capsathin are presented by the coefficients of the proposed model. As indicated by $p$ value, positive linear $(p<0.05)$ effect of time is only confirmed to be significant for PCO yield, while positive linear $(p<$ 0.05) effect of temperature is noticed for capsaicin content present in methanolic PCO. Furthermore, it is found that interactive influence of both variables has the prominent positive effect $(p<0.001)$ for capsaicin content. On the other hand, a negative quadratic effect $(p<0.01)$ has been verified for both variables for capsaicin.

Fig. 4 and 5 show the response surface and contour map for PCO yield and capsaicin. It was observed that the capsaicin content rises as the temperature and time increase, but prolonged phase contact at increased temperature will not be acceptable due to the negative quadratic terms at $p<0.01$. Generally speaking, when a higher extraction temperature was applied to the process, a higher velocity and extraction efficacy were achieved. However, some degradation processes can easily occur at high temperature, resulting in lower analyte recovery. 


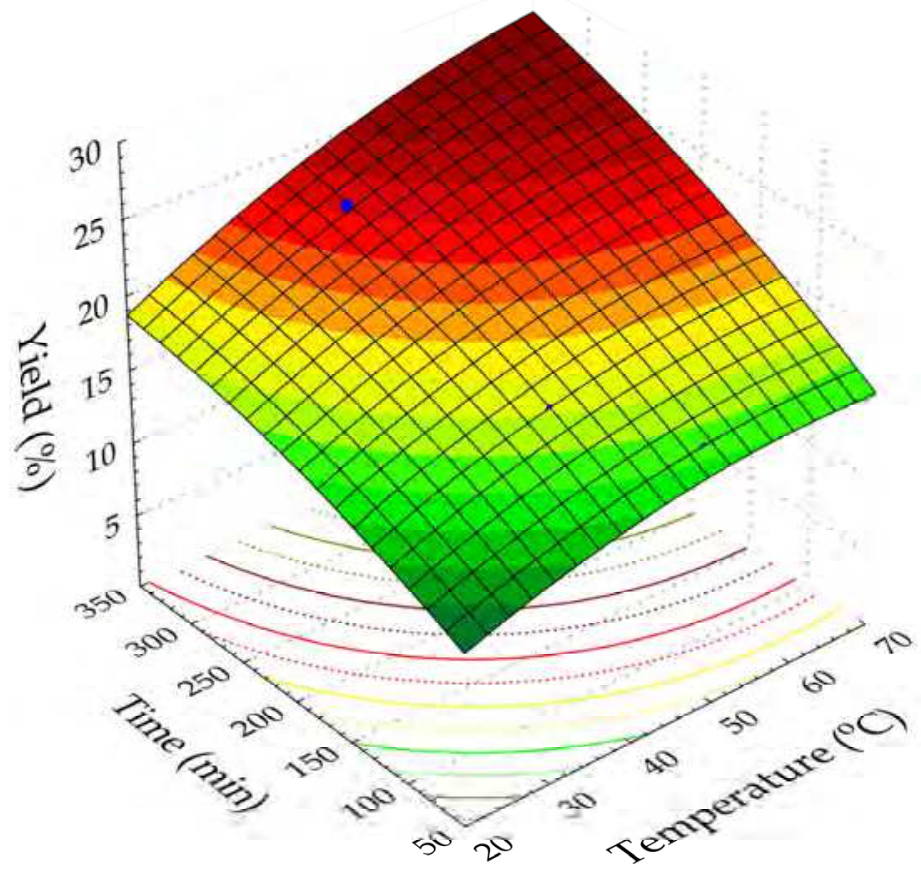

(a)

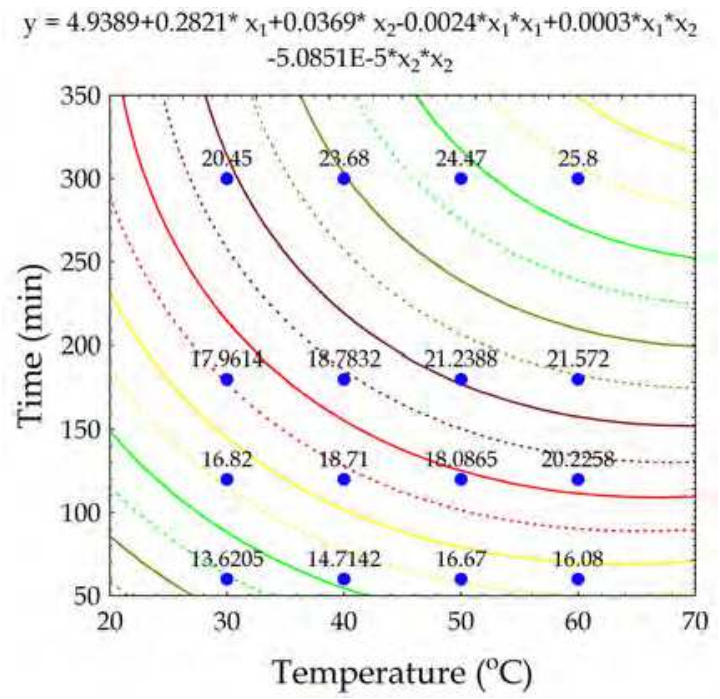

(b)

Fig. 4. 3-D mesh plot (a) and contour plot (b) of the effects of extraction temperature and time on PCO yield (\%) in methanol. 


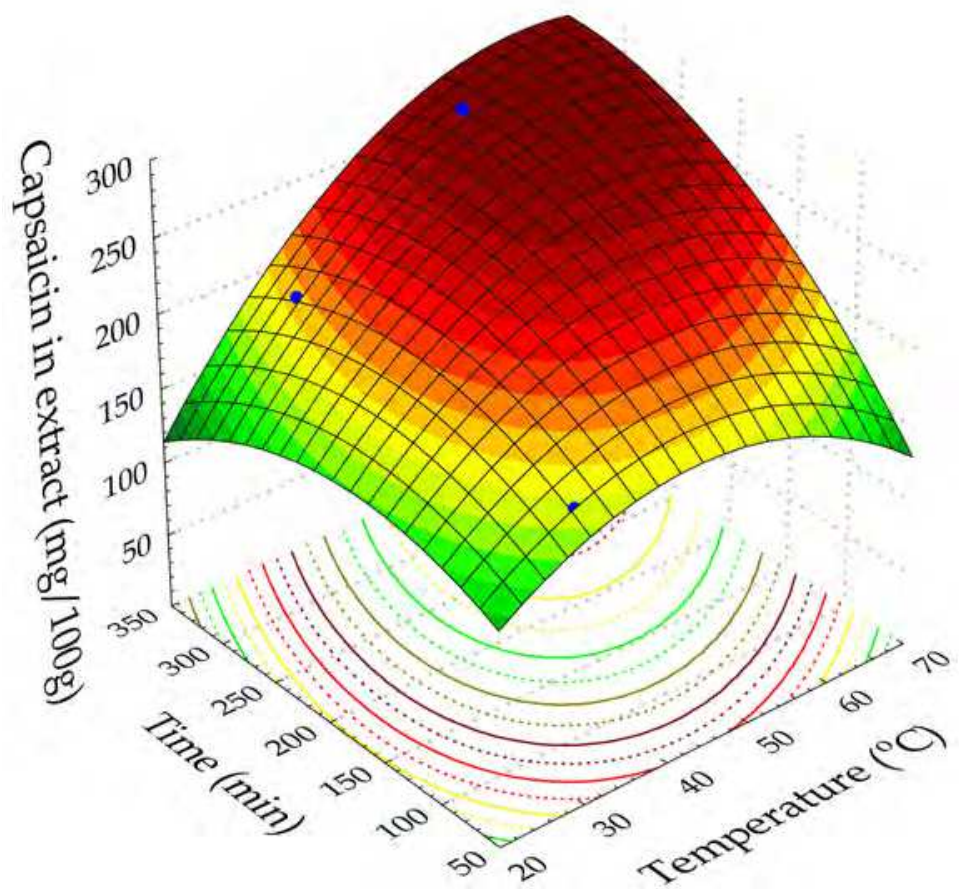

(a)

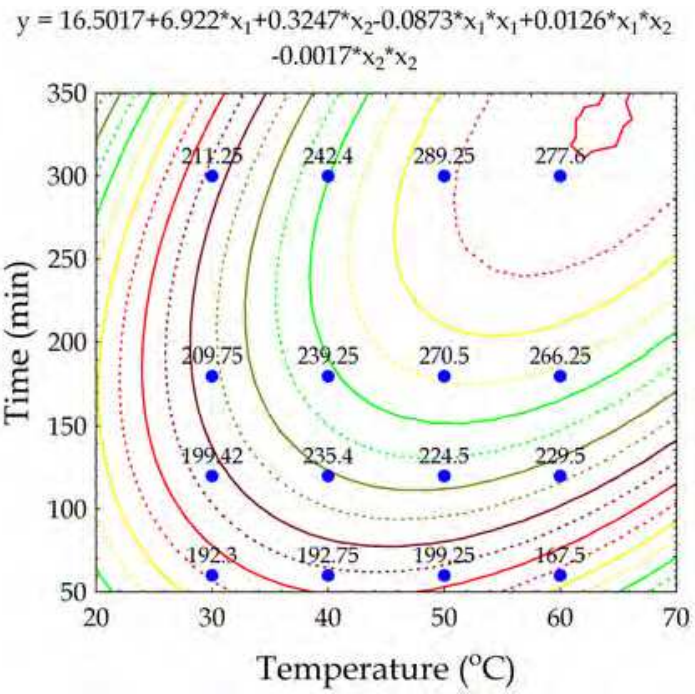

(b)

Fig. 5. 3-D mesh plot (a) and contour plot (b) of the effects of extraction temperature and time on capsaicin in methanolic PCO. 


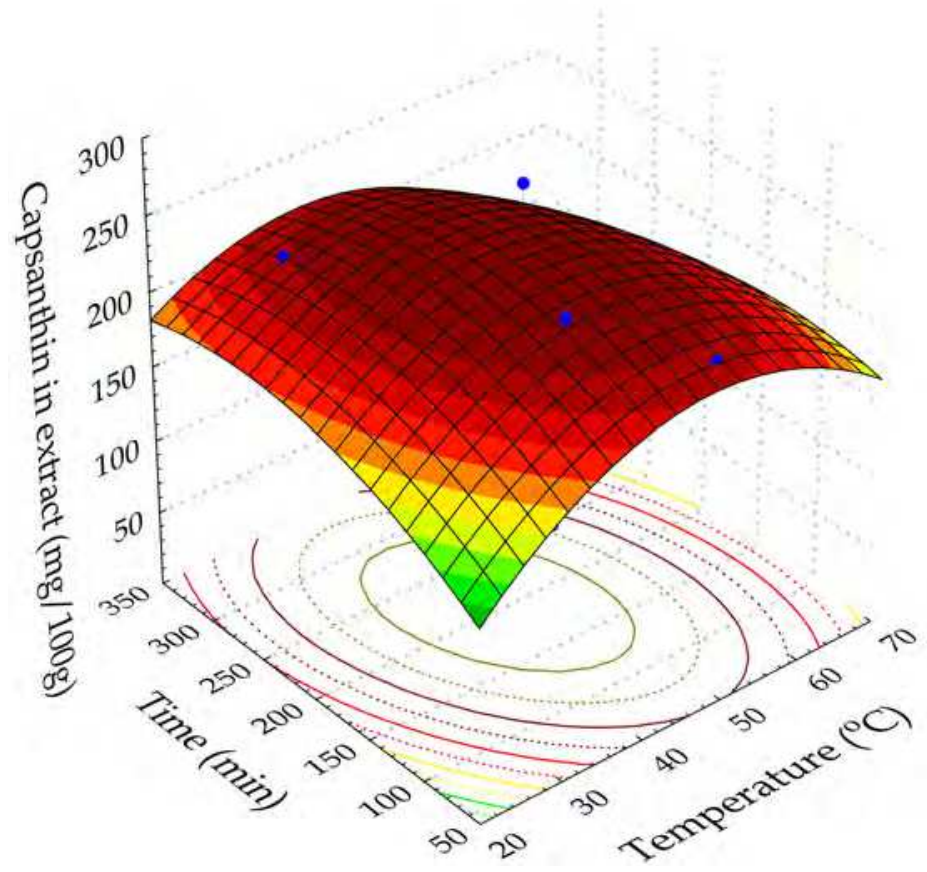

(a)

$$
\begin{gathered}
y=-56.0657+9.7859^{*} x_{1}+0.8087^{*} x_{2}-0.0974^{*} x_{1}{ }^{*} x_{1}-0.0066^{*} x_{1}{ }^{*} x_{2} \\
-0.0013 x_{2}{ }^{*} x_{2}
\end{gathered}
$$

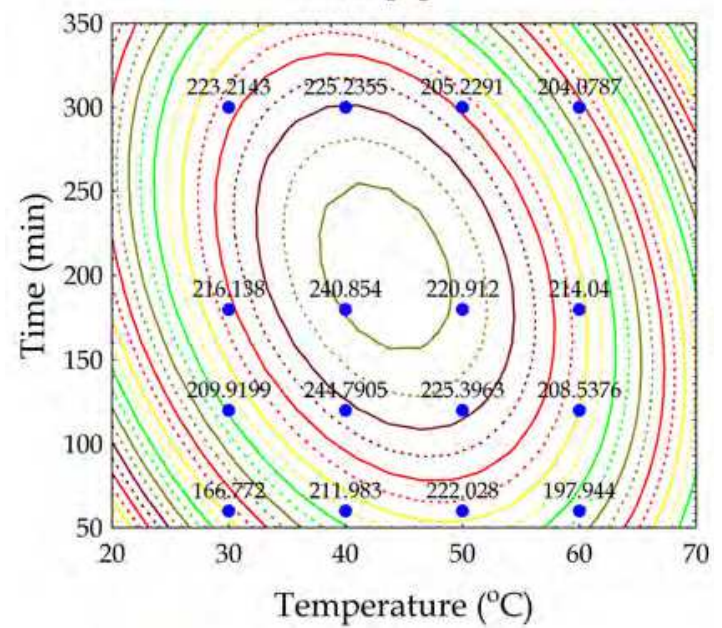

(b)

Fig. 6. 3-D mesh plot (A) and contour plot (B) of the effects of extraction temperature and time on capsanthin in methanolic PCO. 
Consequently, Fig. 6 shows that the conditions for capsanthin extraction with methanol are unsuitable.

\subsection{Extraction of pungent capsicum oleoresin, capsaicin and capsanthin with hexane 3.3.1 Model fitting}

The data obtained by these models demonstrated how the independent variables in the models influenced the extraction efficiency of the analytes of interest when using $n$-hexane. Thus, the liner, quadratic and interactive coefficients of the independent variables in the models and their corresponding $\mathrm{R}^{2}$ when $n$-hexane was used as extraction solvent presented in Table 3.

\begin{tabular}{lccc}
\hline & Yield $(\%)$ & Capsaicin $(\mathrm{mg} / 100 \mathrm{~g})$ & Capsanthin $(\mathrm{mg} / 100 \mathrm{~g})$ \\
\hline $\mathrm{b}_{\mathrm{o}}$ (intercept) & $3.922869^{*}$ & -27.952500 & -1912.489400 \\
$\mathrm{~b}_{1}$ & 0.040339 & $3.445100^{*}$ & $88.014500^{* *}$ \\
$\mathrm{~b}_{2}$ & 0.007445 & $0.300400^{*}$ & $10.158300^{* * *}$ \\
$\mathrm{~b}_{1}{ }^{2}$ & -0.000234 & -0.028000 & $-0.712100^{*}$ \\
$\mathrm{~b}_{2}{ }^{2}$ & -0.000013 & $-0.000600^{*}$ & -0.001500 \\
$\mathrm{~b}_{12}$ & 0.000105 & -0.001900 & $-0.159800^{* * *}$ \\
$R^{2}$ & 0.9482 & 0.7890 & 0.9013 \\
adjusted R 2 & 0.9223 & 0.6836 & 0.8519 \\
$p$ or probability & 0.0000 & 0.0037 & 0.0001 \\
\hline
\end{tabular}

Subscripts: $1=$ temperature $\left({ }^{\circ} \mathrm{C}\right) ; 2$ = time $(\mathrm{min})$;

*Significant at 0.05 level; **Significant at 0.01 level; ***Significant at 0.001 level.

Table 3. Regression coefficients, $R^{2}$, adjusted $\mathrm{R}^{2}$ and $p$ for three dependent variables for pungent capsicum oleoresin obtained by $n$-hexane.

According to the $p$-value, the models appeared to be adequate for the observed data at a $99.9 \%$ confidence level for PCO yield and capsanthin when extraction process was carried out with $n$-hexane. The $\mathrm{R}^{2}$ values, as a measure of the degree of fit, for these response variables, are higher than 0.90 where PCO and capsanthin are concerned, confirming that the regression models adequately explained the extraction process with $n$-hexane. Hence, the $\mathrm{R}^{2}$ values are 0.9482 and 0.9013, respectively, for PCO yield and capsanthin. However, the $\mathrm{R}^{2}$ value of capsaicin is low $\left(\mathrm{R}^{2}=0.7890\right)$ showing lack-of fit and has the less relevant dependent variable in the model. As expected, non-polar components are present in $n$-hexane extracts.

\subsubsection{Influence of extraction temperature and time}

The effect of extraction conditions on the PCO, capsaicin and capsathin are shown by the coefficients of the proposed model and confirmed by assessing the significance of the variables. As can be seen for capsanthin, both time $(p<0.001)$ and temperature $(p<0.01)$ are significant, being affected by the positive sign, while the interaction between temperature and time is significant $(p<0.001)$ with a negative sign. However, it is evident that negative quadratic effect $(p<0.05)$ of temperature is confirmed to be significant for capsanthin indicating that extended phase contact at increased temperature will be inappropriate. Obtained results also confirmed that $n$-hexane is the appropriate choice of solvent for capsanthin extraction. Fig. 7 and 9 show the response surface and contour map for PCO yield and capsanthin. Higher temperature and a longer phase contact decrease the capsanthin content in PCO. 


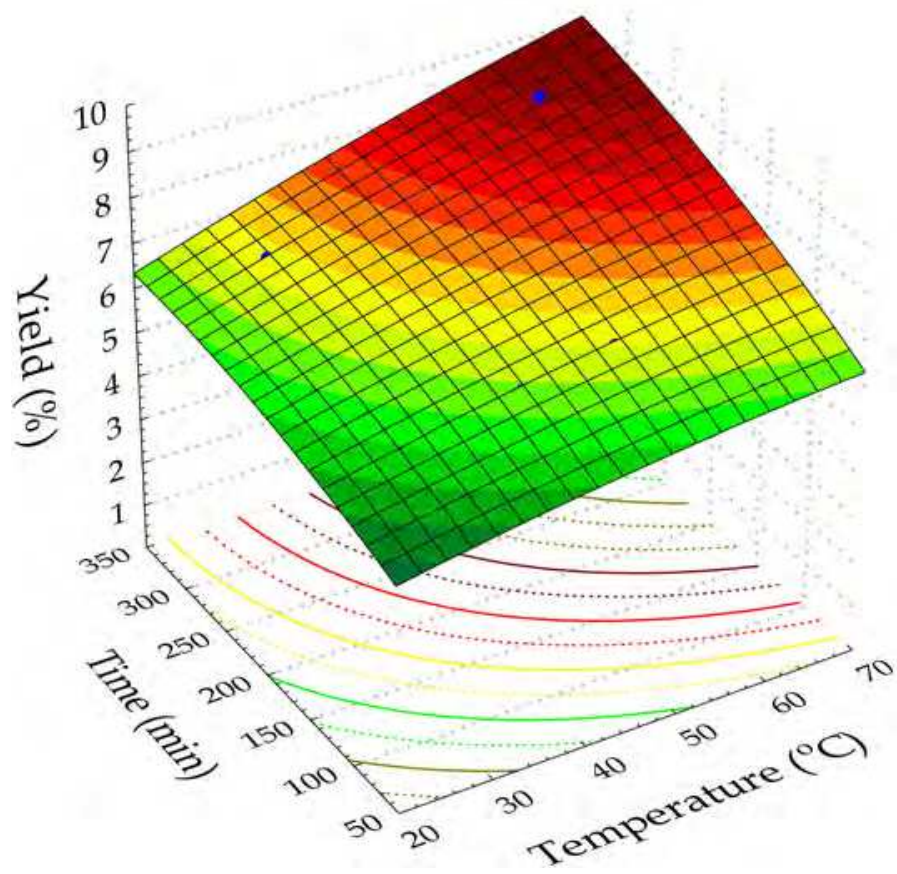

(a)

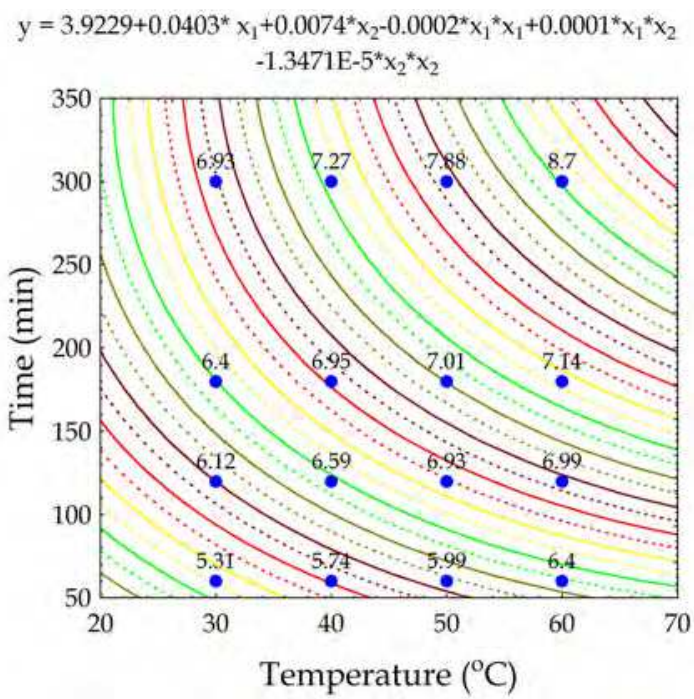

(b)

Fig. 7. 3-D mesh plot (a) and contour plot (b) of the effects of extraction temperature and time on $\mathrm{PCO}$ yield (\%) in $n$-hexane. 


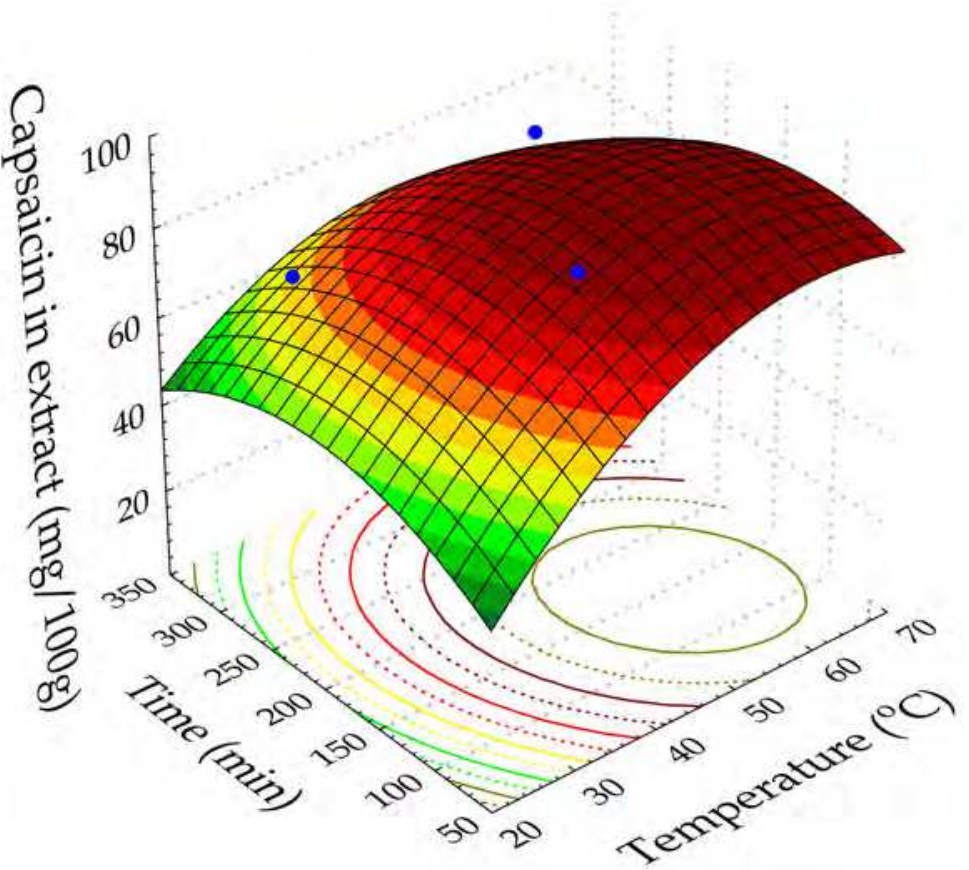

(a)

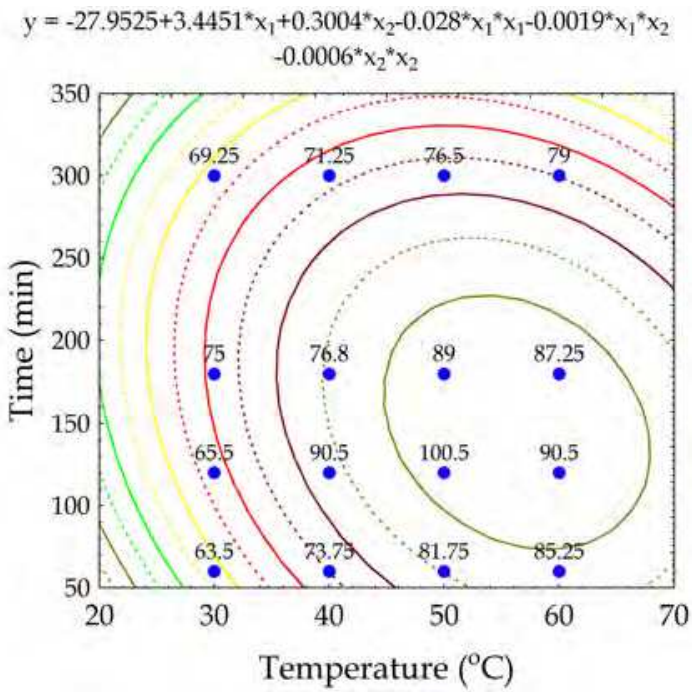

(b)

Fig. 8. 3-D mesh plot (a) and contour plot (b) of the effects of extraction temperature and time on capsaicin in $n$-hexane PCO. 


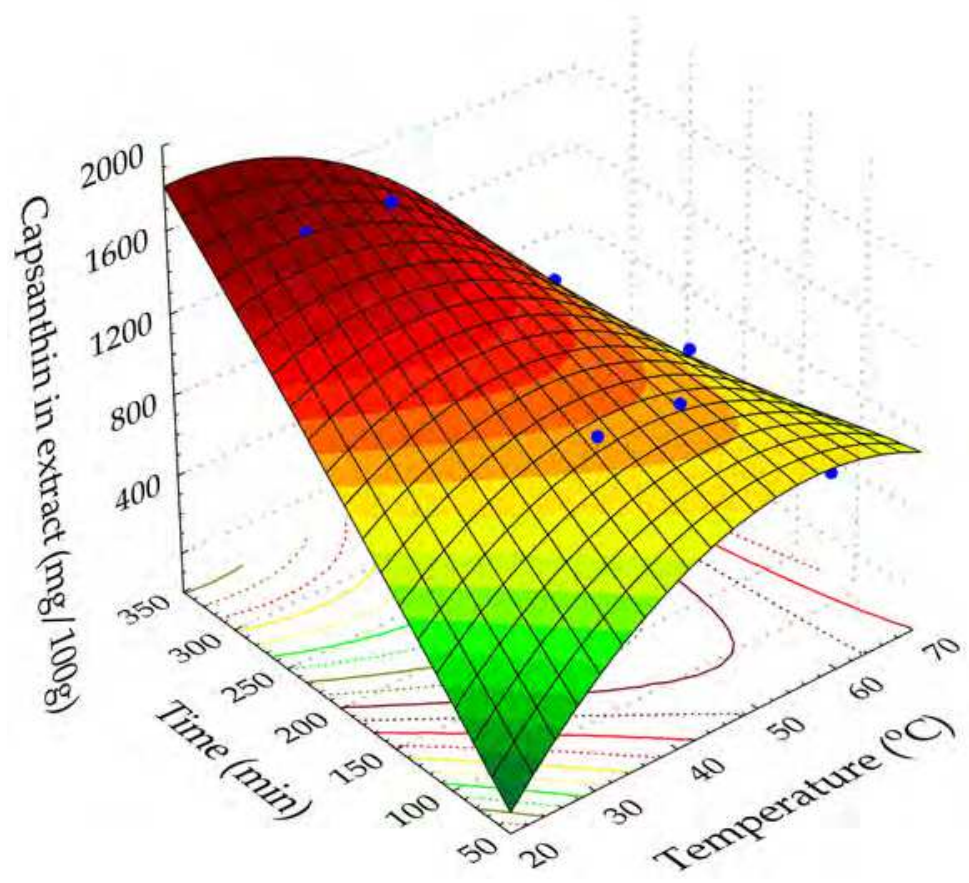

(a)

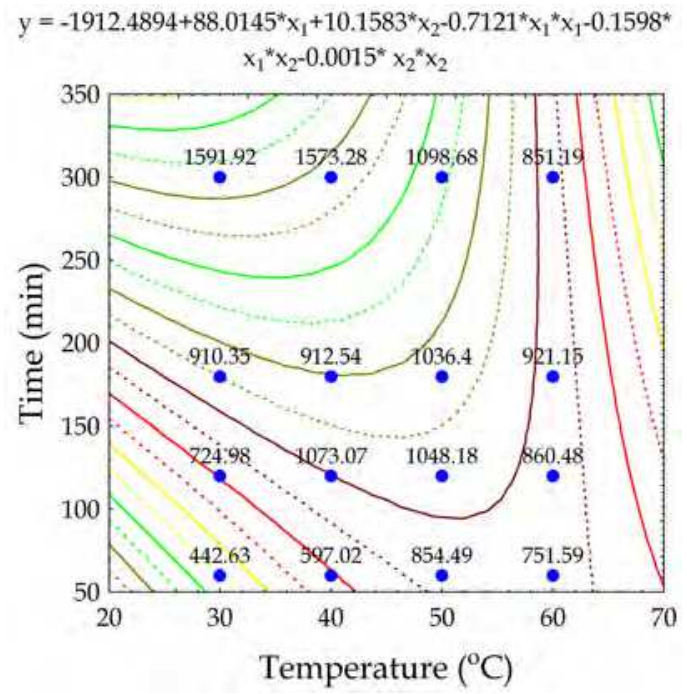

(b)

Fig. 9. 3-D mesh plot (a) and contour plot (a) of the effects of extraction temperature and time on capsanthin in $n$-hexane PCO. 
Fig. 8 clearly shows that $n$-hexane is not the best solvent of choice for extraction of capsaicin.

\subsection{Optimization of extraction conditions}

RSM plays a key role in an efficient identification of the optimum values of the independent variables, under which depend variable could achieve a maximum response. In line with this, the set of optimum extraction conditions were determined by superimposing the contour plots of all the responses (Montgomery, 2001). The criteria applied for the optimization included maximum PCO yield and capsaicin in ethanol and methanol as well as maximum PCO yield and capsanhin in $n$-hexane. Data obtained from the profiles for predicted values and desirability are shown in Table 4 . The desirability was calculated by simultaneous optimization of multiple responses, and ranges from low (0) to high (1). The optimum combined condition for PCO yield and capsaicin in ethanol was found to be at $68^{\circ} \mathrm{C}$ for $165 \mathrm{~min}$. When methanol is used as extraction solvent, the lower temperature for protracted time contributes to maximum PCO yield and capsaicin. Therefore, the optimum combined condition in methanol is confirmed to be at $57^{\circ} \mathrm{C}$ for $256 \mathrm{~min}$. The instability of capsanthin at increased temperature is again confirmed by optimum combined condition in $n$-hexane at $45^{\circ} \mathrm{C}$ for $256 \mathrm{~min}$.

\section{Independent variable}

\begin{tabular}{|c|c|c|c|c|c|}
\hline & Temperature $\left({ }^{\circ} \mathrm{C}\right)$ & Time (min) & Low limit & High limit & Value \\
\hline $\begin{array}{l}\text { Dependent } \\
\text { variable }\end{array}$ & \multicolumn{5}{|c|}{ Ethanol } \\
\hline PCO yield (\%) & 68 & 165 & 11.28 & 21.63 & 19.12 \\
\hline $\begin{array}{l}\text { Capsaicin } \\
(\mathrm{mg} / 100 \mathrm{~g})\end{array}$ & 68 & 165 & 118.45 & 290.71 & 269.00 \\
\hline $\begin{array}{l}\text { Capsanthin } \\
(\mathrm{mg} / 100 \mathrm{~g})\end{array}$ & 35 & 256 & 195.85 & 303.75 & 293.46 \\
\hline $\begin{array}{l}\text { Dependent } \\
\text { variable }\end{array}$ & \multicolumn{5}{|c|}{ Methanol } \\
\hline PCO yield (\%) & 57 & 256 & 12.38 & 26.23 & 23.73 \\
\hline $\begin{array}{l}\text { Capsaicin } \\
(\mathrm{mg} / 100 \mathrm{~g})\end{array}$ & 57 & 256 & 158.04 & 297.82 & 283.10 \\
\hline $\begin{array}{l}\text { Capsanthin } \\
(\mathrm{mg} / 100 \mathrm{~g})\end{array}$ & 45 & 165 & 178.93 & 250.71 & 210.65 \\
\hline $\begin{array}{l}\text { Dependent } \\
\text { variable }\end{array}$ & \multicolumn{5}{|c|}{ n-Hexane } \\
\hline PCO yield (\%) & 56 & 256 & 5.14 & 8.41 & 8.00 \\
\hline $\begin{array}{l}\text { Capsaicin } \\
(\mathrm{mg} / 100 \mathrm{~g})\end{array}$ & 50 & 165 & 59.27 & 100.14 & 92.84 \\
\hline $\begin{array}{l}\text { Capsanthin } \\
\text { (mg/100g) }\end{array}$ & 45 & 256 & 351.32 & 1554.66 & 1054.92 \\
\hline
\end{tabular}

Table 4 . The optimum combined condition predicted values for dependent variables at optimal values of variables. 


\subsection{Verification of predicted model}

The PCO yield, capsaicin and capsanthin contents of the examined red pungent dried paprika fruit sample were calculated based on the optimized conditions of the proposed maceration method and compared with experimental values of the response variables. The verification of the obtained results requires good agreement between values calculated using the model equations and experimental value of the responses (Table 5).

\begin{tabular}{lccc}
\hline & PCO yield $(\%)$ & Capsaicin $(\mathrm{mg} / 100 \mathrm{~g})$ & Capsanthin $(\mathrm{mg} / 100 \mathrm{~g})$ \\
\hline & Ethanol (time=165 min; temperature $\left.=65^{\circ} \mathrm{C}\right)$ & \\
\hline Predicted value & 18.69 & 263.14 & 240.86 \\
Experimental value & 19.63 & 261.98 & 242.22 \\
\hline & Methanol (time=256 min; temperature $\left.=45^{\circ} \mathrm{C}\right)$ & \\
\hline Predicted value & 22.33 & 268.07 & 232.86 \\
Experimental value & 23.01 & 267.13 & 233.56 \\
\hline & $n$-Hexane $\left(\right.$ time $=256 \mathrm{~min} ;$ temperature $\left.=45^{\circ} \mathrm{C}\right)$ & 1267.49 \\
\hline Predicted value & 7.49 & 86.07 & 1264.12 \\
\hline
\end{tabular}

Table 5. Predicted and experimental value for the response at optimum conditions.

\section{Conclusion}

Surface plots were generated to describe the relationship between two operating variables and predicted responses.

Methanol and ethanol were confirmed to be superior and were chosen as the extraction solvents of first choice for the PCO and capsaicin under studied process condition. Regarding capsanthin, it is apparent that $n$-hexane offers optimal values with the highest desirability.

Process conditions, i.e. optimal extraction time and temperature with the highest desirability of analytes content of interest, were developed and verified.

\section{References}

Acero-Ortega, C.; Dorantes, L.; Hernández-Sánchez, H.; Tapia, M. S.; Gutiérrez-López, G.; Alzamora, S. \& López-Malo, A. (2005). Response surface analysis of the effects of Capsicum extract, temperature and $\mathrm{pH}$ on the growth and inactivation of Listeria monocytogenes. Journal of Food Engineering, Vol.67, 247-252. 
Ahmeda, J.; Shivhareb, U. S. \& Ramaswamyc, H. S. (2002). A fraction conversion kinetic model for thermal degradation of color in red chilli puree and paste. LebensmittelWissenschaft und Technologie, Vol.35, No.6, 497-503.

Barbero, G. F.; Palma, M. \& Barroso C. G. (2006). Determination of capsaicinoids in peppers by microwave-assisted extraction-high-performance liquid chromatography with fluorescence detection. Analytica Chimica Acta, Vol.578, 227-233.

Bo, W.; Jianzhong, W.; Liangcheng, Z.; Xiaoping, G. \& Guogang, M. (2008). Optimization for ultrasonic wave extraction of red pigment from paprika by response surface method. Chinese Agricultural Science Bulletin, Vol.6, 96-101.

Boonkird, S.; Phisalaphong, C. \& Phisalaphong, M. (2008). Ultrasound-assisted extraction of capsaicinoids from Capsicum frutescens on a lab- and pilot-plant scale. Ultrasonics Sonochemistry, Vol.15, 1075-1079.

Boyadzhiev, L.; Kancheva, D.; Guiraud, P. \& Gourdon, C. (1999). On carotenoids and capsaicin extraction from red paprika (Capsicum annum L.) fruits. Hungarian Journal of Industrial Chemistry, Vol.27, 37-41.

Cvetkov, Lj. \& Rafajlovska, V. (1992). Choice of suitable solvent for oleoresin extraction from grinded spicy pepper. Bulletin of the Chemists and Technologists of Macedonia, Vol.11, 61-66.

Davis, C. B.; Markey, C. E.; Busch, M. A. \& Busch, K. W. (2007). Determination of capsaicinoids in habanero peppers by chemometric analysis of UV spectral data. Journal of Agricultural and Food Chemistry, Vol. 55, 5925-593.

De Marino, S.; Iorizzi, M. \& Zollo, F. (2008). Antioxidant activity and biological properties of phytochemicals in vegetables and spices (Capsicum, Laurus, Foeniculum). Electronic Journal on Environmental, Agricultural and Food Chemistry (EJEAFChe), Vol.7, No.10, 3174-3177.

Dorantes, L.; Colmenero, R.; Hernández, H.; Mota, L.; Jaramillo, M. E.; Fernández, E. \& Solano, C. (2000). Inhibition of growth of some foodborne pathogenic bacteria by Capsicum annum extracts. International Journal of Food Microbiology, Vol.57, 125-128.

Feltl, L.; Pacáková, V.; [tulík K. \& Volka, K. (2005). Reliability of carotenoid analyses: A Review, Current Analytical Chemistry, Vol.1, 93-102.

Giovanni, M. (1983). Response surface methodology and product optimization. Food Technology, Vol.37, 41-45.

Giovannucci, E. (2002). Lycopene and prostate cancer risk. Methodological considerations in the epidemiologic literature. Pure Applied Chemistry, Vol.74, 1427-1434.

Govindarajan, V. S. \& Sathyanarayana, M. N. (1991). Capsicum: Production, technology, chemistry \& quality; Part V. Impact on physiology, nutrition \& metabolism, structure, pungency, pain and desensitisation sequences. Critical Reviews in Food Science and Nutrition, Vol.29, 435-474.

Guzman, I.; Bosland, P.W. \& O'Connell, M.A. (2011). Heat, Color, and Flavor Compounds in Capsicum Fruit, In: The Biological Activity of Phytochemicals, Vol. 41, D. R. Gang, (Ed.), 109-126, Springer Science+Business Media, ISBN 978-1-4419-6961-3, Springer, New York, Dordrecht, Heidelberg, London. 
Hismath, I.; Wan Aida, W. M. \& Ho, C. W. (2011). Optimization of extraction conditions for phenolic compounds from neem (Azadirachta indica) leaves. International Food Research Journal, Vol.18, 59-67.

Hoffman, P. G.; Lego, M. C. \&. Galetto, W.G. (1983). Separation and quantification of red pepper major heat principles by reverse-phase high pressure liquid chromatography. Journal of Agricultural and Food Chemistry, Vol.31, 1326-1330.

Hornero-Méndez, D.; Gómez-Ladrón de Guevara, R. \& Mínguez- Mosquera, M. I. (2000). Carotenoid biosynthesis changes in five red pepper (Capsicum annuum L.) cultivars during ripening. Cultivar selection for breeding. Journal of Agricultural and Food Chemistry, Vol. 48, 3857-3864.

Howard, R. L.; Smith, T. R.; Waguer, B. A.; Villason, B. \& Burns, E. E. (1994). Provitamin A and ascorbic acid content of fresh pepper cultivars Capsicum annuum and processed jalapenos. Journal of Food Science, Vol.59, No.2, 362-365.

Ji-Hye, K.; Goto, T.; In-Seob, H.; Teruo, K.; Young, M. K. \& Rina,Y. (2010). Dietary capsaicin reduces obesity-induced insulin resistance and hepatic steatosis in obese mice fed a high-fat diet, Obesity, Vol.18, No.4, 780-787.

Kense, W. (1970). Solid-liquid extraction with a Carousel-type extractor. Chemiker-Zeitung, Vol.94, No.2, 56-62.

Kirschbaum-Titze, P.; Mueller-Seitz, E. \& Petz, M. (2002). Pungency in paprika (Capsicum annuиm). 2. Heterogeneity of capsaicinoid content in individual fruits from one plant. Journal of Agricultural and Food Chemistry, Vol.50, No.5, 1264-1266.

Li, Q. H. \& Fu, C. L. (2005). Application of response surface methodology for extraction optimization of germinant pumpkin seeds protein. Food Chemistry, Vol.92, 701706.

Liu, Q. M.; Yang, X. M.; Zhang, L. \& Majetich, G. (2010). Optimization of ultrasonicassisted extraction of chlorogenic acid from Folium eucommiae and evaluation of its antioxidant activity. Journal of Medicinal Plants Research, Vol.4, No.23, 25032511.

Materska, M. \& Perucka, I. (2005). Antioxidant activity of the main phenolic compounds isolated from hot pepper fruit (Capsicum annuum L.). Journal of Agricultural and Food Chemistry, Vol.53, No.5, 1750-1756.

Matsufuji, H.; Nakaura, H.; Chino, M. \& Takeda, M. (1998). Antioxidant activity of capsanthin and the fatty acids esters in paprika (Capsicum annuum). Journal of Agricultural and Food Chemistry, Vol.46, 3468-3472.

Montgomery, D.C. (2001). Fitting regression model, Response surface methods and other approaches to process optimization, In: Design and Analysis of Experiments, 392510, John Wiley \& Sons, Inc., ISBN 0-471-31649-0, New York.

Nowaczyk, P.; Nowaczyk, L.; Banach M. \& Woźna A. (2008). The capsaicin and dihydrocapsaicin contents in soft-flesh fruit of Capsicum frutescens L. and Capsicum annuum L. hybrids. Herba Polononica, Vol.52, No.1-2, 38-42.

Pérez-Gálvez, A.; Rios, J. J. \& Mínguez-Mosquera, M. I. (2005). Thermal degradation products formed from carotenoids during a heat-induced degradation process of paprika oleoresins (Capsicum annuum L.). Journal of Agricultural and Food Chemistry, Vol.15, No.12, 4820-4826. 
Pruthi, J. S. (2003). Chemistry and quality control of Capsicum and Capsicum products, In: Capsicum, genus Capsicum, Vol. 35, A. De Krishna, (Ed.), 25-70, Taylor and Francis Ltd., ISBN 0-415-29991-8, London and New York.

Rafajlovska, V.; Slaveska-Raicki, R.; Koleva-Gudeva, L. \& Klopceska, J. (2007). Spice paprika oleoresin extraction under different conditions involving acetone and ethanol. Journal of Food, Agriculture and Environment, Vol.5, No.2, 65-69.

Rajaraman, K.; Kuty-Sumathy, A. M.; Sankarikutty, B. \& Mathew, G. A. (1981.) Ethylacetat as solvent for extraction of spice oleoresins. Journal of Food Science Technology, Vol.18, 101-103.

Reyes-Escogido, M. L.; Gonzalez-Mondragon, E. G. \& Vazquez-Tzompantzi. E. (2011). Chemical and pharmacological aspects of capsaicin. Molecules, Vol.16, 12531270 .

Schweiggert, U.; Kurz, C.; Schieber, A. \& Carle, R. (2007). Effects of processing and storage on the stability of free and esterified carotenoids of red peppers (Capsicum annuum L.) and hot chilli peppers (Capsicum frutescens L.). European Food Research and Technology, Vol.225, No.2, 261-270.

Singh, T. \& Chittenden, C. (2008). In-vitro antifungal activity of chilli extracts in combination with Lactobacillus casei against common sapstain fungi. International Biodeterioration and Biodegradation, Vo.62, No.4, 364-367.

Spicer, Jr. O. L. \& Almirall R. J. (2005). Extraction of capsaicins in aerosol defense sprays from fabrics. Talanta, Vol.67, 377-382.

Tepić, A.; Zeković, Z.; Kravić, S. \& Mandić, A. (2009). Pigment content and fatty acid composition of paprika oleoresins obtained by conventional and supercritical carbon dioxide extraction, Journal of Food, Vol. 7, No.2, 95-10.

Toma, M.; Vinatoru, M.; Paniwnyk, L . \& Mason, T. J. (2001). Investigation of the effects of ultrasound on vegetal tissues during solvent extraction. Ultrasonics Sonochemistry, Vol.8, 137-142.

Vinatoru, M. (2001). An overview of the ultrasonically assisted extraction of bioactive principles from herbs, Ultrasonic Sonochemistry, Vol.8, 303-313.

Vinaz, P.; Camoilo, N.; Gardia-Lopez, I. \& Cordoba-Hernandez, M. (1992). Liquid chromatographic determination of fat-soluble vitamins in paprika and paprika oleoresin. Food Chemistry, Vol.45, 349-355.

Wang, L. \& Weller, C. L. (2006). Recent advances in extraction of nutraceuticals from plants. Trends in Food Science and Technology, Vol.17, 300-312.

Weisshaar E., Dunker, N. \& Gollnick, H. (2003). Topical capsaicin therapy in humans with hemodialysis-related pruritus. Neuroscience Letters, Vol.345, 192-194.

Willams, O. J.; Raghavan G. S. V.; Orsat, V. \& Dai, J. (2007). Microwave-assisted extraction of capsaicinoids from Capsicum fruits. Journal of Food Biochemistry, Vol.28, No.2, 113122.

Xing, F. B; Cheng, G. X. \&, Yi, K. K. (2006). Study on the antimicrobial activities of the capsaicin microcapsules. Journal of Applied Polymer Science, Vol.102, No.2, 1318-1321.

Xiu-Ju, L.; Jun, P. \& Yuan-Jian, Li. (2011). Recent advances in the study on capsaicinoids and capsinoids, European Journal of Pharmacology, Vol.650, 1-7. 
Ying-Yue, W.; Chi-Tzong, H.; Wen-Ta, C. \& Jia-You, F. (2001). In vitro and in vivo evaluations of topically applied capsaicin and nonivamide from hydrogels. International Journal of Pharmaceutics, Vol.224, 89-104. 


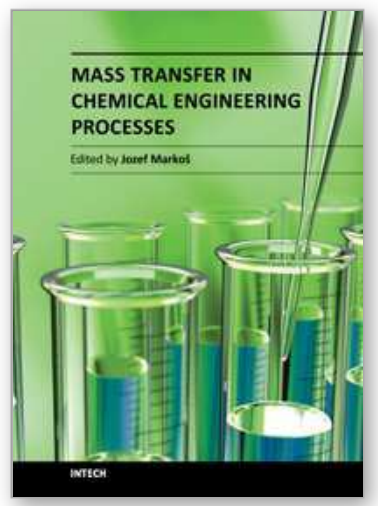

\author{
Mass Transfer in Chemical Engineering Processes \\ Edited by Dr. Jozef Marko $\AA_{i}$
}

ISBN 978-953-307-619-5

Hard cover, 306 pages

Publisher InTech

Published online 04, November, 2011

Published in print edition November, 2011

This book offers several solutions or approaches in solving mass transfer problems for different practical chemical engineering applications: measurements of the diffusion coefficients, estimation of the mass transfer coefficients, mass transfer limitation in separation processes like drying, extractions, absorption, membrane processes, mass transfer in the microbial fuel cell design, and problems of the mass transfer coupled with the heterogeneous combustion. I believe this book can provide its readers with interesting ideas and inspirations or direct solutions of their particular problems.

\title{
How to reference
}

In order to correctly reference this scholarly work, feel free to copy and paste the following:

Vesna Rafajlovska, Renata Slaveska-Raicki, Jana Klopcevska and Marija Srbinoska (2011). Extraction of Oleoresin from Pungent Red Paprika Under Different Conditions, Mass Transfer in Chemical Engineering Processes, Dr. Jozef Marko $\AA_{i}$ (Ed.), ISBN: 978-953-307-619-5, InTech, Available from:

http://www.intechopen.com/books/mass-transfer-in-chemical-engineering-processes/extraction-of-oleoresinfrom-pungent-red-paprika-under-different-conditions

\section{INTECH}

open science | open minds

\section{InTech Europe}

University Campus STeP Ri Slavka Krautzeka 83/A 51000 Rijeka, Croatia Phone: +385 (51) 770447 Fax: +385 (51) 686166 www.intechopen.com

\section{InTech China}

Unit 405, Office Block, Hotel Equatorial Shanghai No.65, Yan An Road (West), Shanghai, 200040, China 中国上海市延安西路65号上海国际贵都大饭店办公楼 405 单元 Phone: +86-21-62489820

Fax: +86-21-62489821 
(C) 2011 The Author(s). Licensee IntechOpen. This is an open access article distributed under the terms of the Creative Commons Attribution 3.0 License, which permits unrestricted use, distribution, and reproduction in any medium, provided the original work is properly cited. 